\title{
ASSESSING BRAZILIAN PERIPHERAL SPRAWL: AN ASSOCIATION OF COMPUTER-AIDED TOOLS TO EVALUATE SPATIAL CHANGES AT VILA CABRAL NEIGHBORHOOD, CAMPINA GRANDE
}

\section{ANALISANDO A DISPERSÃO PERIFÉRICA NO BRASIL: UMA ASSOCIAÇÃO DE FERRAMENTAS COMPUTACIONAIS PARA AVALIAR AS TRANSFORMAÇÕES ESPACIAIS NO BAIRRO VILA CABRAL, CAMPINA GRANDE}

\author{
Frederico Costa ${ }^{1}$, Jaqueline Brandão ${ }^{1}$, Geovany Silva ${ }^{1}$
}

\begin{abstract}
:
This article presents an analysis of the spatial transformations between 2005 and 2020 in the Vila Cabral neighborhood, at Campina Grande's suburbs, a medium-sized Brazilian city located in the interior of the Paraíba state. The main objective of this research is to evaluate the efficiency of the proposed methodological association to conduct studies related to urban growth in Brazil, analyzing the characteristics of this process in the sample studied. From a methodological perspective, this study uses a quanti-qualitative analysis of a homogeneous urban fabric sample. We built two different analytical scenarios (2005 and 2020) for comparison. The following procedures were developed: (i)literature review, (ii)formal decomposition of a sample of the urban fabric; (iii)Angular Segment Analysis (ASA/Space Syntax); (iv)parametric analysis of the diversity of uses; and (v)parametric analysis of urban density (population and built). In the end, it was possible to objectively evaluate and understand the transformations that occurred in the time-lapse of the two scenarios. The discussions proposed by this research orbit Brazil's current urban growth model and how objective indicators can assist the diagnostic task. This investigation reinforces that the association of different urban analysis methodologies can strengthen the diagnostic processes. The objective metrics addressed can improve decision-making and support designers to propose cities with more quality.
\end{abstract}

KEYWORDS: spatial analysis tools; parametric urban analysis; angular segment analysis; space syntax.

\section{RESUMO:}

Este artigo trata dos aspectos relacionados ao crescimento urbano periférico e das transformações espaciais ocorridas entre os anos de 2005 e 2020 no bairro Vila Cabral, localizado na periferia de Campina Grande, uma cidade média brasileira situada no interior do estado da Paraíba. O principal objetivo desta pesquisa é avaliar a eficiência da associação metodológica proposta para realização de estudos relacionados ao crescimento urbano no Brasil, analisando as características desse processo na amostra estudada. O estudo lança mão de uma análise quanti-qualitativa em uma amostra homogênea do tecido urbano, realizando os seguintes procedimentos: (i) revisão de literatura, (ii) decomposição formal do tecido urbano; (iii) Análise Angular de Segmentos (ASA / Sintaxe Espacial); (vi) análise paramétrica da diversidade de usos; e (v) análise paramétrica da densidade urbana (populacional e construída). Foram elaborados dois cenários analíticos distintos (2005 e 2020), para então comparar os resultados. Ao final, foi possivel avaliar objetivamente as transformações ocorridas entre os dois cenários, com as discussões propostas orbitando o modelo atual de crescimento urbano no Brasil e qual o papel dos indicadores objetivos em tarefas de diagnóstico. A investigação reforça que a associação de diferentes metodologias de análise urbana fortalece os processos de diagnóstico. As métricas objetivas abordadas podem incrementer a tomada de decisões e auxiliar os projetistas na proposição de cidades com maior qualidade espacial.

PALAVRAS-CHAVE: ferramentas de análise espacial; análise urbana paramétrica; análise angular de segmentos; sintaxe espacial.

How to cite this article:

COSTA, F.; BRANDÃO, J.; SILVA, G. Assessing Brazilian peripheral sprawl: an association of computer-aided tools to evaluate spatial changes at Vila Cabral neighborhood, Campina Grande. Gestão \& Tecnologia de Projetos. São Carlos, v17, n1, 2022. https://doi.org/10.11606/gtp.v17i1.183854
${ }^{1}$ Federal University of Paraíba - Postgraduate Program in Architecture and Urbanism (PPGAU UFPB)

Fonte de Financiamento: Coordenação de Aperfeiçoamento de Pessoal de Nível Superior - CAPES

Conflito de Interesse: Declara não haver.

Submetido em: 15/07/2021 Aceito em: 17/08/2021 


\section{INTRODUCTION}

This paper was firstly presented in a short version at the congress of the Sociedad Iberoamericana de Gráfica Digital - SIGraDi 2020. This expanded version reports a synthesis of urban design quality investigations applying a set of tools to assess the built environment on the scale of the city. The study was carried out within the research group Performance and Innovation applied to Design (DIAProj), hosted at the Federal University of Paraíba. Our efforts aim to analyze the urban form and territorial occupation related to peripheral urban sprawl paradigms, applying three distinct and complementary methodologies.

Van Nes, Berghauser Pont, and Mashhoodi (2012) point out that the association of different computational design tools (CDT) allows designers to develop complementary assessments. They found results that contribute to better diagnosing the role of spatial aspects in the socioeconomic processes of a city. Porter and De Roo (2012) understand that actors involved in urban planning intend to control or interfere in space, and that is why they will be busy with decision-making. The urban planning paradigm based on technical-rational thinking promotes approaches that fail to recognize opportunities to solve complex problems. These approaches deny introducing new CDT, which increases the gap between science and practice. Many of these available CDT assist in evaluating the built environment's spatial properties related to different methodologies. They can support spatial analysis as a fundamental methodological approach in the urban morphology field (DE ROO, 2013; STEINØ; VEIRUM, 2005).

In this context, we assume that associate methodologies allow us to better understand an urban growth process and help strengthen the decision-making process. Thus, our article describes a quanti-qualitative approach to the Vila Cabral neighborhood's formal and spatial transformation processes, emphasizing the changes between 2005 and 2020 scenarios. We took this neighborhood as our study sample because of the empirical perception of its accelerated growth in the last fifteen years. As in Vila Cabral, several other neighborhoods in Brazilian medium-sized cities have a similar urbanization process, enhanced by specific buildings and private capital attracting infrastructure. This sample will allow us to generalize the urban growth pattern for other cases in Brazilian cities.

The neighborhood is located in the peripheral area of Campina Grande, a medium-sized city located in the interior of Paraíba state, $125 \mathrm{~km}$ far from the state capital João Pessoa (Figure 1). The city is in the Brazilian semi-arid region, in a privileged geographical position between the hinterland and the coast of Paraíba state. It is an important regional economic, industrial, and educational hub, with a population equal to 409.7 thousand inhabitants (COSTA, 2013; IBGE, 2019; MAIA, 2010).

Figure 1. Identification of the study sample, the Vila Cabral neighborhood, located at Campina Grande, Paraíba, Brazil.

Source: the authors.

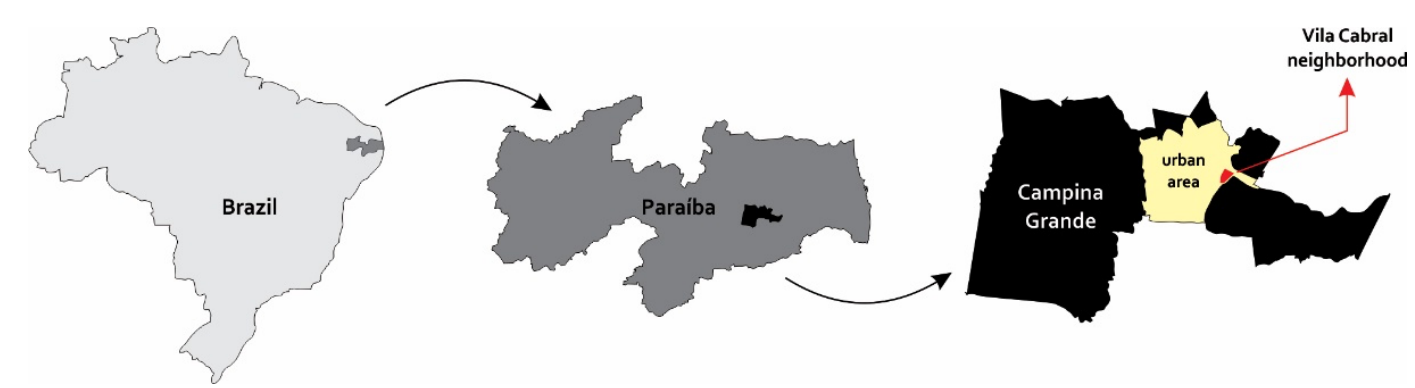


We start from empirical evidence that the construction of the UNIFACISA University Center (2005) and the Heron Marinho Business \& Living (2011) acted as attraction equipment. They leveraged the urban transformation of the neighborhood in their vicinity. Thus, these buildings possibly accentuated land use and occupation changes, promoting an increase in the dispersion pattern after the beginning of other private real estate investments, such as new vertical and horizontal condominiums already under construction in the region (Figure 2).

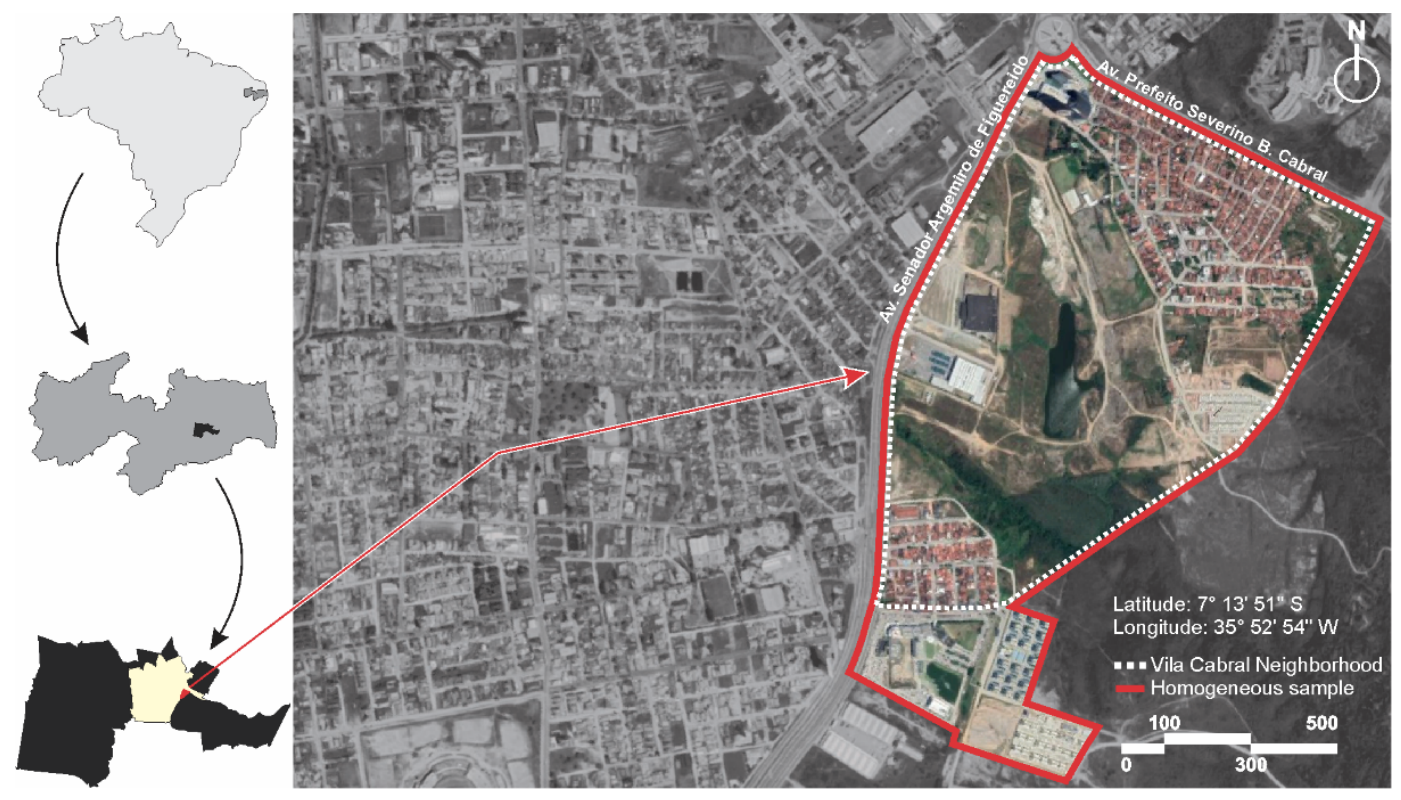

According to Araújo (2019), Vila Cabral was characterized predominantly by irregular and selfconstructed occupations. However, in the last years, the city has become attractive for social agents that enhance the production of the urban space, especially those that operate under the influence of private capital. These agents articulate more profitable strategies for their enterprises by promoting real estate speculation, concentrating their investments in the periphery, regions known to have a lower market value (COSTA, 2013; GUIMARÃES, 2016; MAIA, 2013).

Then, this article discusses the Brazilian urban space production model and its reflexes on the urban environment's quality, evaluating indicators presented and described in this paper's scope. We also intended to reflect on how the association of different methodologies can enhance diagnostic tasks and improve design decision-making, emphasizing the urban environment quality. We seek to understand better the behavior of objective urban indicators (diversity, built density, and populational density) and other spatial metrics related to space syntax (integration and choice) in analyzing the urban growth paradigm widespread in Brazil.

\section{THE URBAN SPACE PRODUCTION AND THE PERIPHERAL SPRAWL IN BRAZILIAN CITIES}

Guimarães (2016) states that the capitalist model's socio-spatial production results from many agents oriented to private interests. Approaching the urbanization process and the urban space production at Campina Grande, Maia $(2010 ; 2013)$ and Costa (2013) points out axes of urban expansion in the city. These axes characterize a process of the urban fabric's dispersion to the peripheral regions. According to the author, this process has attracted the real estate sector's
Figure 2. The figure identifies the urban fabric and the Vila Cabral neighborhood's immediate surroundings in 2020, as the two equipment taken by the research hypothesis: Heron Marinho Business \& Living and the UNIFACISA University Center..

Source: the authors. 
attention and stimulated land speculation, especially after concluding robust projects, such as supermarkets, university centers, and horizontal closed condominiums.

To better understand the phenomenon of urban space production, we first conducted this investigation in the field of urban geography. We choose to shed some light on urban space production based on two fundamental authors to build this research corpus: Corrêa (2004) and Capel (2013). The authors approach the theme of urban space production from different perspectives and classifications but converge on similar concepts.

According to the definition presented by Corrêa (2004), he classified the social agents that influence the urban form as (i) the owners of the means of production in the industrial, commercial, and service sectors; (ii) landowners who seek to increase the land rent from their properties through speculation and trade in rural land through the transition from rural to urban space; (iii) real estate developers who can act in several areas such as development, financing, technical-constructive feasibility study, construction of properties and commercialization; (iv) the state, which serves as a real estate developer by promoting housing subsidies, promotes the infrastructure of the urban space and prepares urban legislation related to land use; and (v) excluded social groups, which comprise the low-income population without access to housing.

In Capel's understanding (2013), all citizens act and enjoy the city. However, only a few have the power to interfere in the urban form: urban agents. According to their classification proposal, these agents may be (i) owners of the land; (ii) the owners of the means of production; (iii) real estate developers; and (iv) the state.

After this short conceptualization by both authors, we can see that they have different ways of interpreting and classifying the urban space-producing agents. Corrêa (2004) and Capel (2013) follow the same line of reasoning, diverging on the performance and influence of citizens. According to Capel (2013, p.18, translated by the authors), "all citizens move and act in the city, use it, enjoy it and experience it. But few have the real capacity to intervene in its construction and development". The citizens are categorized only as Social Actors, except those more involved with urban social movements. They are no longer simple actors to exercise decision-making power, becoming effectively Urban Agents. According to Corrêa (2004), the population that does not have access to housing, classified as the excluded social agents, also influences urban space production. They act, predominantly, in the transformations of peripheral areas (peripheral area urban growth).

The consolidation of the urbanization process is a product of different agents' actions, making cities complex. The influence of the slow and late industrialization process that Brazil went through affected the consolidation of urban spaces in the country. With colonial roots and a predominantly rural and agricultural population until the beginning of the 20th century, Brazil only experienced the first significant urban transformations after 1930. This transformation happens through a redefinition of the state's role, investments, and new strategies that drove the country's emergence of the industrial economic sector. Until then, the backbone of the Brazilian economy was essentially agro-export. This industrialization process resulted in significant economic, social, and urban changes, driving the rural exodus, city population growth, and demographic growth (GUIMARÃES, 2016; SANTOS, 1993;).

The displacement of people from the countryside to urban centers looking for a job and quality of life resulted in population growth and an accelerated urbanization process. Also, the increase in the birth rate and decreased mortality rate due to sanitary progress enhanced this process. We can associate the populational growth with the total urban population to understand this process better. In 1940's Brazil, the rate of urbanization was 26,35\%, with a total urban population equal to 10,8 million people, rising to $68,86 \%$ in 1980 , totaling 82 
million people in the cities. About this period, Santos (1993, p.29, translated by the authors) pointed out that "In these forty years, the total population of Brazil triples, while the urban population multiplies by seven and a half times." In this period, the country is experiencing strong economic growth, of more than 7\% per year. In 1991 the urban population reached 115,7 million inhabitants with an urbanization rate of $77,1 \%$. The cities received more than 100 million people in the 50 years (MARICATO, 2015; SANTOS, 1993).

Guimarães (2016) states that capitalism influences the historical urbanization process in Brazil, promoting an urban growth model composed of two main motions. The first is related to increased populational and built density, stimulating high-rise buildings in central areas. The second enhances peripheral dispersion, expanding the limits of the urban fabric. These motions are responsible for significant changes in the cities shape, impacting land use and occupation. This model was reproduced profusely in several Brazilian medium-sized cities, which started to play an essential role in the national cities network. They became connection centers between large and small cities, just like Campina Grande's city (MAIA, 2010).

This model, analyzed by the theoretical base that underlies this research, can be considered problematic and has contributed to a significant increase in the cost of managing and maintaining urban infrastructure. It also enhances the consumption of natural resources, affecting cities' dynamics, imposing difficulties on pedestrian mobility, and increasing dependence on conventional means of transport (FARR, 2007; GEHL, 2013; NETTO; KRAFTA, 2009; ROGERS, 1998). This research emphasizes the peripheral dispersion identified in the city of Campina Grande by Maia (2010). In addition to those cited here, some authors have already pointed out that urban sprawl impacts several aspects of life quality, causing even public health problems (EWING et al., 2003; FRUMKIN, 2002; FRUMKIN et al., 2004). Thus, the compact city paradigm will be briefly addressed in this paper's next section.

\section{COMPACITY, SPRAWL AND URBAN DESIGN: A SHORT REVIEW}

The problems arising from this investigation's urban growth model have been a recurring theme in scientific research in developed and developing countries. In the context of several kinds of research, there is a clear proposal for reflection on the impacts that urban space's formal properties have on the metropolitan area's quality. One of the problems related to the low-density urban growth model is the increasing demand for more automobiles and highways to connect an excessively fragmented urban fabric. Data from the Global Fuel Economy (2016) point out that the burning of fossil fuels released into the atmosphere by motor vehicles is responsible for up to $75 \%$ of air pollution in cities. The World Health Organization (2012) associates this pollution with 3,7 million premature deaths in 2012. (BEREITSCHAFT; DEBBAGE, 2013; BRUECKNER, 2000; LIMA et al., 2019; NECHYBA; WALSH, 2004; NETTO; KRAFTA, 2009; NECHYBA; WALSH, 2004; NEWMAN; KENWORTHY, 2000; SQUIRES, 2002).

Another common point in these researches is that urban design can help city rehabilitation, emancipating the automotive dependence resulting from the urban growth model exposed here. These authors oppose this model of urban dispersion and discuss alternatives in the field of urban sustainability. They understand that cities must become compact, capable of offering alternative means of transport and with a diversity of uses and equipment per urbanized square area (DUANY; PLATER-ZYBERK, 1992; FREY 2003; KENWORTHY; LAUBE, 1996; NEWMAN; KENWORTHY, 1989, 2000, 2006; RUEDA, 1997; TALEN, 2011).

Therefore, it is understood that the urban form becomes an essential condition for more sustainable cities. Thus, the paradigm of compact cities, with bigger built and population densities, walkable, with good public and green spaces, emerges as an alternative for circular urban metabolism and a lower environmental footprint (KENNEDY et al., 2007). Dantzig and 
Saaty (1973) suggest that the compact city is an alternative to reduce urban expansion. Rogers (1998) reinforces that compactness is directly associated with the autonomy of an urban center: compact cities are more sustainable, justifying that compactness is responsible for optimizing energy resources and reducing the level of pollution (fewer trips), in addition to offering advantages as the diversity of uses, shortening distances in the urban fabric between home and workplace (JABAREEN, 2006; JENKS et al., 2000; JENKS et al., 2005).

Berghauser Pont and Haupt (2010) understand that increasing urban areas' compactness is essential for a more sustainable city model. Chakrabarti (2014) points out that the spread of the urban mesh is the leading cause of problems in cities. The author highlights climate change, high health and public education costs, and unemployment due to market competitiveness. Glaeser (2012) and Chakrabarti (2014) converge about other potentialities of compact cities or more compact ones: they favor the exchange of ideas, labor, and human capital, stimulating, through this dynamism, economic prosperity and the more sustainable and autonomous market development, as the authors state.

It is important to reinforce that the high urban density paradigm assumes that its benefits can only be fully viable through an adequate infrastructure, or as Chakrabarti (2014) defines, the infrastructure of opportunity: schools, cultural centers, hospitals, health centers, parks, and other fundamental social facilities that enable social aspirations such as employment, education, leisure, and health.

\section{METHODOLOGICAL PROCEDURES}

As the central element of this investigation's approach, we choose the association between three different methodologies/CDT for studying urban space. We focus on laying down both a formal and a spatial analysis process to evaluate and understand the urban fabric's transformations objective attributes and visual aspects. Introducing the methodological procedures (Figure 3), we developed a quanti-qualitative analysis of the Vila Cabral neighborhood through (i) decomposition of the urban fabric from a homogeneous sample, as proposed by Coelho (2013); (ii) angular segment analysis (ASA), as stated by Turner (2001) as an alternative for investigating the relationships of urban configuration under the Social Logic of Space, exposed by Hillier and Hanson (1984), applying the software DepthMapX (version 0.30 ) to analyze aspects of space syntax (e.g., normalized angular integration - NAIN; normalized angular choice - NACH); (iii) an objective analysis of the diversity of uses, applying mixed-use indexes); and (iv) the built urban density and the population density (net and gross). The indexes and indicators (steps iii and iv) data were collected and analyzed by the algorithmic-parametric logic exposed by Lima, Costa, and Rosa (2020) and structured through the Grasshopper components (Rhinoceros3D software plugin), organized to carry out this research in addition to two other clusters named "Spacematrix" and "MXI," tools from the CityMetrics system developed by Lima et al. (2019). 


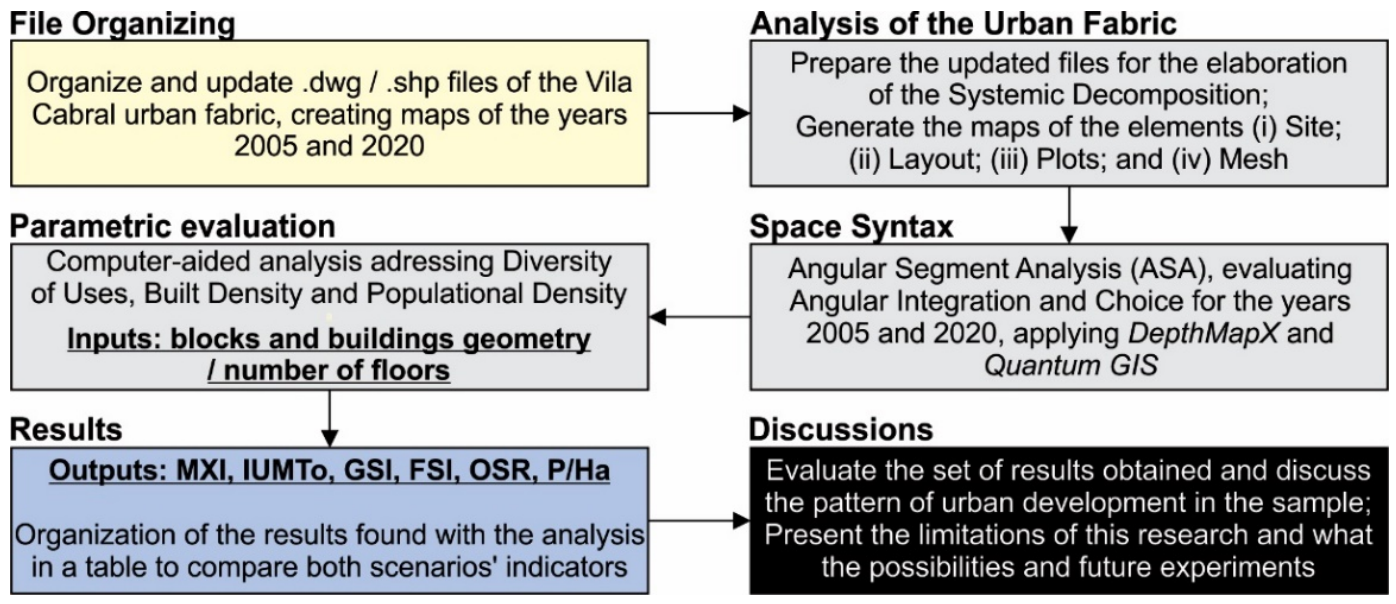

The analysis of the spatial configuration was carried out through the Angular Segment Analysis - (ASA), proposed by Turner (2001). It is a methodological procedure to investigate the relationships of the urban configuration under the Social Logic of Space (HILLIER; HANSON, 1984). According to Kolovou et al. (2017), this analysis can help understand movement, land use, and socioeconomic patterns, being applied initially in maps of axial segments and later in Road Center Line (RCL) maps. Firstly, to perform the ASA, we created the 2005 and 2020 RCL maps of Campina Grande in .dxf format. It was done from the compatibility of the information between the RCL map developed by Gurgel (2016) and the images captured in the historical image tool of Google Earth.

Then, to perform the comparative analysis of the urban expansion within the established time frame, the spatial representations were processed in the DepthMapX (version 0.30). This software allows us to obtain the standardized syntactic measures of Integration and Choice. Normalized Angular Integration (NAIN) refers to the potential movement of space, describing the greater or lesser accessibility of a segment, referring to the minimum number of inflections between one point and another. Therefore, it measures the distance from one segment to all others in the system (HILLIER et al., 2012). The Normalized Angular Choice (NACH), on the other hand, refers to the movement forecast, describing the potential passage movement and, therefore, a hierarchical choice of urban routes (HILLIER et al., 2012; YAMU et al., 2021).

From this processing, a visual analysis of the syntactic measures was made by reading the chromatic color scale with color grading between red and blue, representing greater or lesser values of integration and choice, respectively. Then, the maps were exported to Quantum GIS, allowing the processing and analysis of statistical measures with the Space Syntax Toolkit plugin developed by Gil et al. (2015). In this step, we generate the numerical results of the syntactic analysis and then start the parametric analysis step.

A 3D model was built for the two scenarios in a digital environment (Rhinoceros3D + Grasshopper) to provide a quick visualization and better understand the transformations analyzed relating to 2005 and 2020 (Figure 4). We adopted the Vila Cabral neighborhood's boundary (determined by the Campina Grandes' city hall) as our sample in 2005. The sample contains the plot which Heron Marinho Business \& Living started to be built in 2011. Then, in the 2020 scenario, we added the plots for UNIFACISA and the two new vertical condominiums under construction between 2014 and 2017.
Figure 3. Synthesis of the methodological procedures applied in this investigation.

Source: the authors. 
Figure 4. Parametric analysis (Rhinoceros3D and Grasshopper) in progress.

Source: the authors.

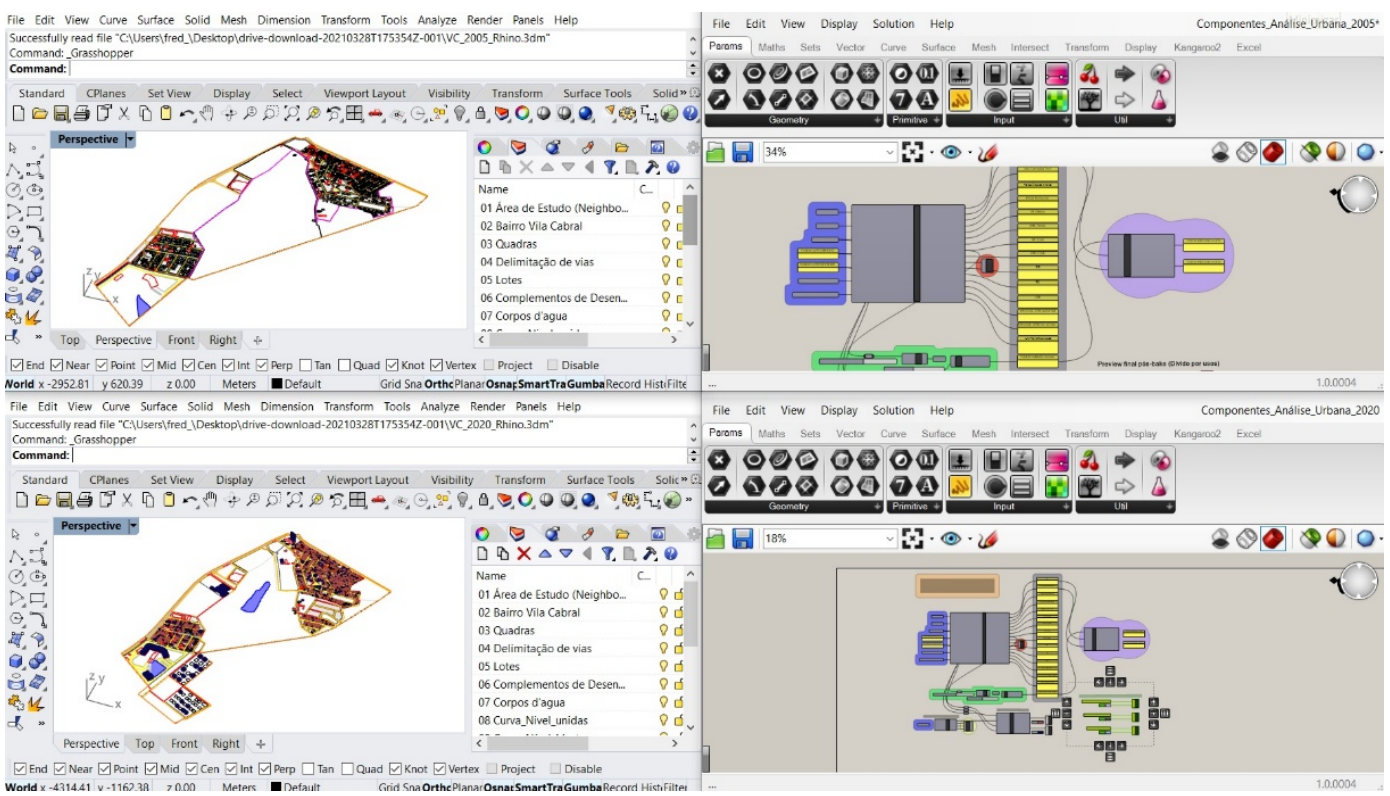

The Grasshopper components are introduced in the last step, starting with the cluster that evaluates the Mixed-Use Index (MXI) developed by Hoek (2008). The diversity of uses considering all vertical floors is evaluated in sequence by implementing a cluster of CityMetrics that evaluates the IUMTo, proposed by Silva (2021). To evaluate the Spacematrix built density indicators, proposed by Berghauser Pont and Haupt (2010), another cluster of CityMetrics is also implemented. Finally, the last cluster is implemented to assess the populational density (gross/net), which was developed especially for this study.

\section{THE MXI AND IUMTO MIXED-USE INDEXES}

The mixed-use Index (MXI), developed by Hoek (2008), tries to establish a relationship between the total residential and non-residential built areas. The MXI weighs the total sum of the entire area in all buildings. It included all floors above ground level (street level), verifying the balance/mix of uses considering the sample verticalization. Hoek (2008) states that when the ratio between the total areas approaches the balance, the urban diversity is close to the ideal. Consequently, the greater the diversity of uses in the area.

The mixed-use index IUMTo, proposed by Silva (2021), aims to establish a similar mathematical relationship between residential and non-residential built areas. However, the IUMTo index emphasizes only the street level (1 $1^{\text {st }}$ floor). The IUMTo allows verifying the diversity of uses and the influence of each street in the urban mesh.

\section{THE SPACEMATRIX BUILT DENSITY INDICATORS}

To carry out the analysis of built density were evaluated three fundamental indicators proposed by Berghauser Pont and Haupt (2010): (i) Total land occupied (Ground Space Index - GSI; (ii) Vertical use in areas where the soil is occupied (Floor Space Index - FSI) and (iii) proportion of open spaces (Open Space Ratio - OSR).

The GSI represents a relationship between the sample and the projections of buildings on the ground. It can be obtained through a ratio between the total area and the sum of the building's soil areas. The FSI represents how much the projections of buildings in the sample are used, which can be obtained by dividing the total constructed area (also considering the vertical 
floors) and the sample area. The OSR can be obtained by dividing the total soil area occupied by buildings (GSI) by the total built area (FSI).

\section{RESULTS}

Through the urban fabric's decomposition in both scenarios (Figure 5), it was possible to visualize the transformations related to Campina Grande's urban fabric mentioned by Maia (2010). The consolidation of two distinct regions in the neighborhood occurs because of the topographic characteristics, limiting the neighborhood's expansion axis. The Systemic Decomposition also showed that both regions are located near the two buildings addressed in this study's hypothesis. So, it is visible the influence they had in encouraging the region's sprawl.
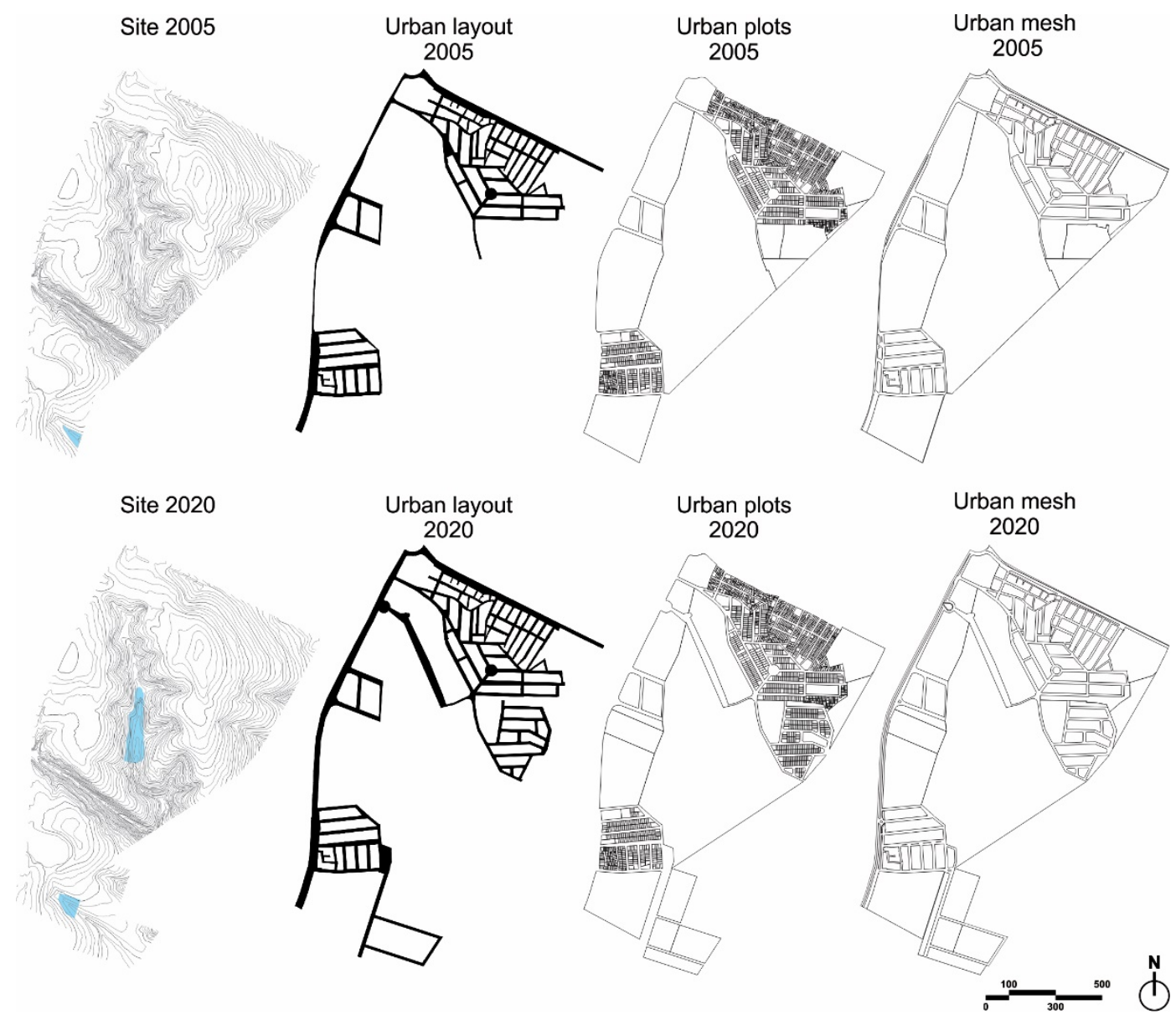

The processing of the standard syntactic measures of Integration (NAIN) and Choice (NACH) allowed the comparative analysis between 2005 and 2020. The configurational analysis of the city on a global scale $(\mathrm{Rn})$ found a core with higher NAIN values in the center of the city and surrounding neighborhoods in both scenarios. We verified these results through the chromatic scale that converges to red. The NAIN analysis on a local scale was processed considering a radius of 1200 meters (15 minutes of walking). The result exposed three decentralized cores with higher integration values in both scenarios. We also verified these results by colors converging to red. Outside these cores, there is an increase in the number of spaces with less accessibility in the 2020 scenario (less integrated spaces). These results are represented by colors that converge to blue on the global scale (Rn) and the local scale (R1200). 
Regarding the Normalized Choice (NACH) for global scale (Rn), the axes of expansion of Campina Grande are evident in the two maps (2005 and 2020). As a highlight, it is possible to see the main structuring routes of the city in shades that converge to the red. On the local scale (R1200), there is a decrease in the number of roads with potential for choice and a dispersion of the higher values for the city's peripheral areas. This fact demonstrates a range of average levels for the local NACH values on the city scale, indicating little difference in pedestrians' short trips' hierarchical choice.

The strengthening of connections between the perimeter roads and the main access roads to the most central regions of the city increased the neighborhood's internal roads' integration values globally (Rn) and locally (R1200). Likewise, there was an increase in the potential for choice, emphasizing the growth in the values of through-movement potential in the primary connection route that connects the southwest and east city regions.

Figure 6. 2005 Angular Segment Analysis Global NAIN/NACH..

Source: the authors.
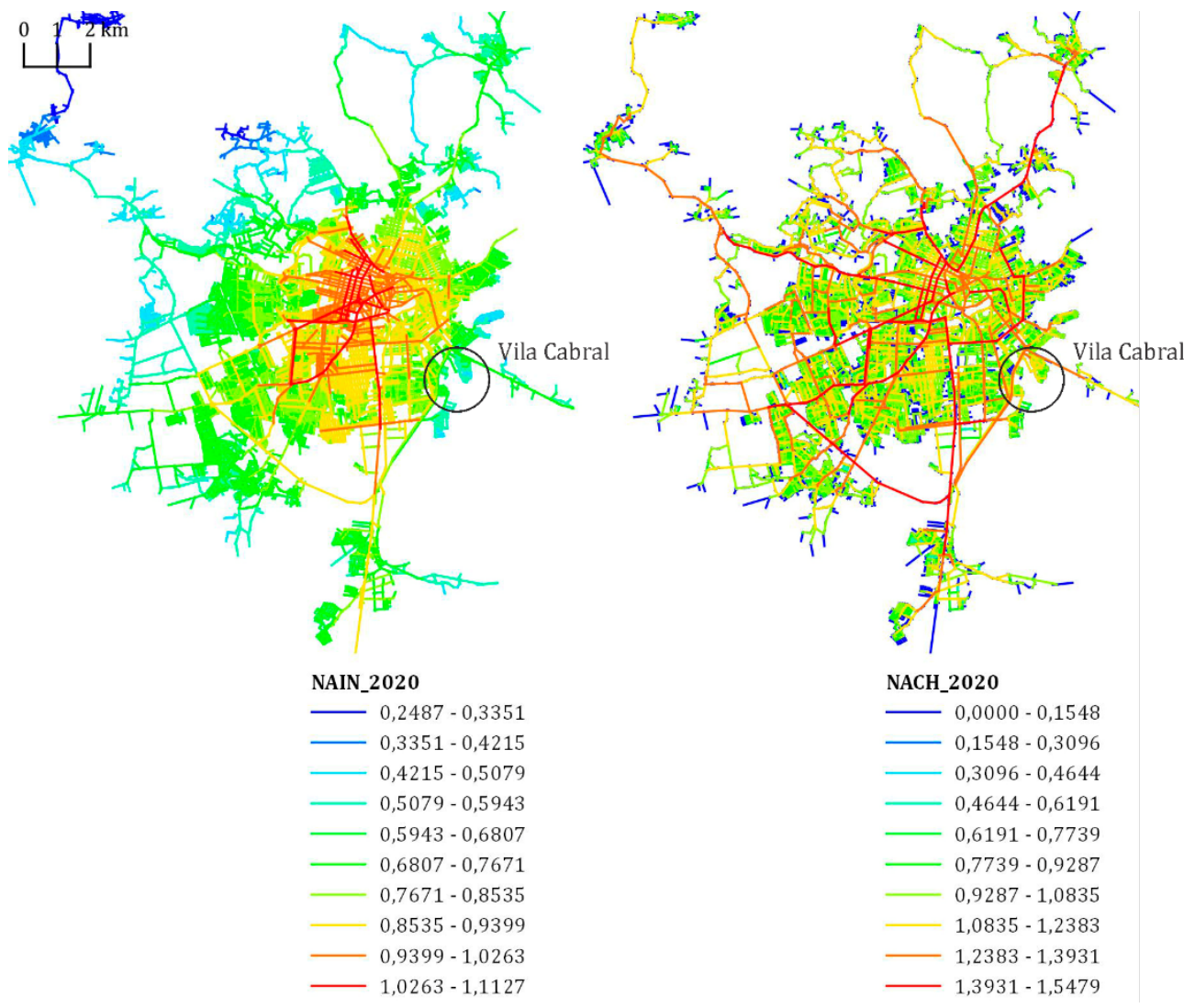

NACH_2020

$-0,0000-0,1548$

- $0,1548-0,3096$

$-0,3096-0,4644$

- $0,4644-0,6191$

$-0,6191-0,7739$

$0,7739-0,9287$

$0,9287-1,0835$

$1,0835-1,2383$

- 1,2383-1,3931

- 1,3931- 1,5479 


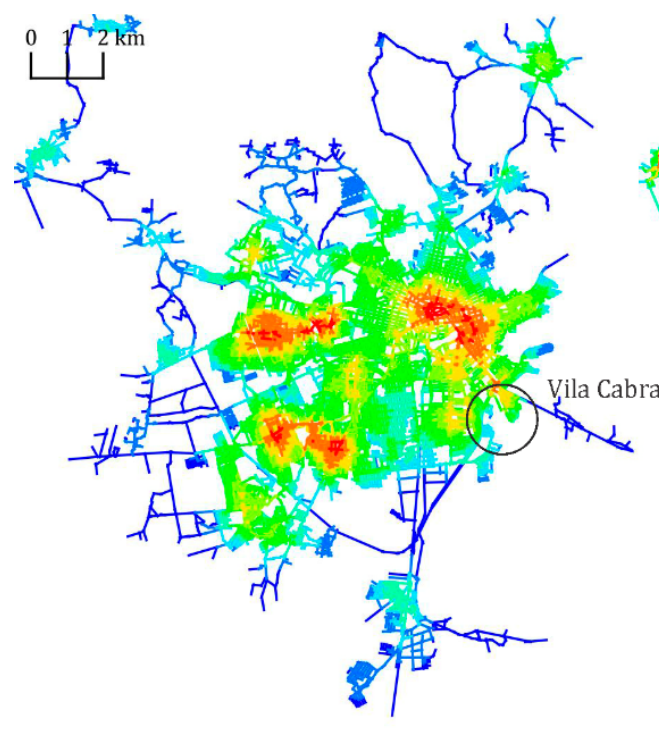

NAIN_R1200_2020

- $0,0153-0,1918$

- $0,1918-0,3683$

- $0,3683-0,5449$

- $0,5449-0,7214$

- $0,7214-0,8979$

- $0,8979-1,0744$

- $1,0744-1,2509$

— $1,2509-1,4274$

$1,4274-1,6039$

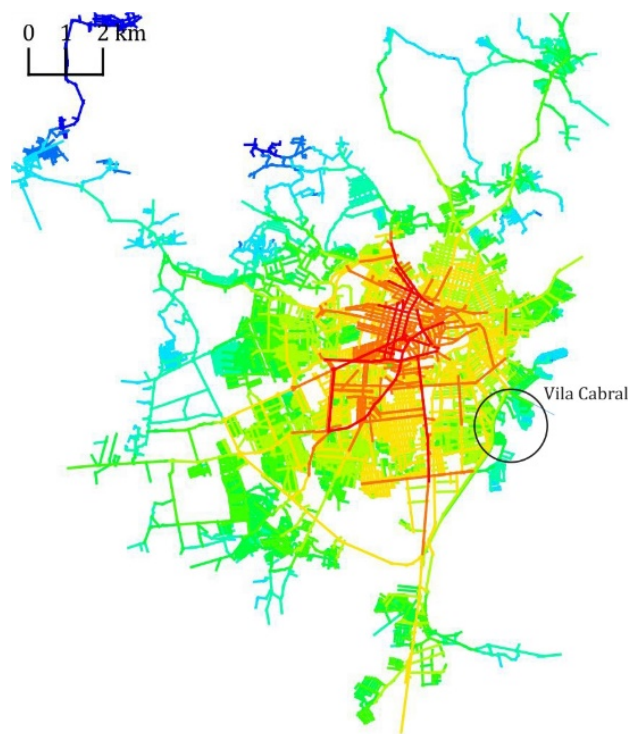

NAIN_2020

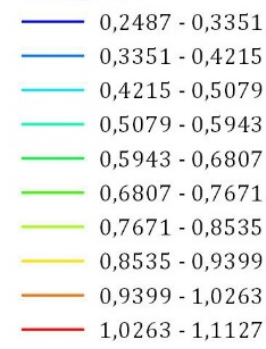

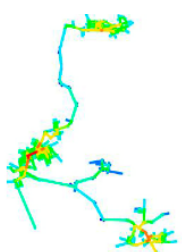
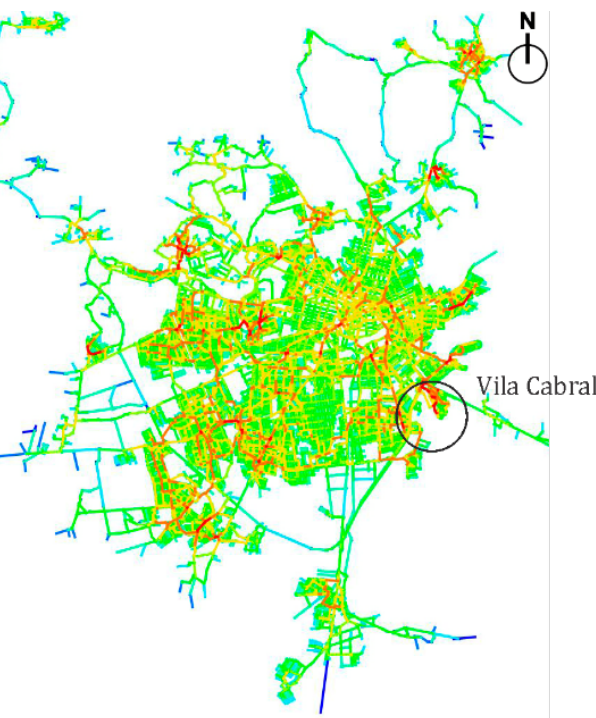

NACH_R1200_2020

- 0,3026-0,3574

- $0,3574-0,4122$

- $0,4122-0,4670$

- $0,4670-0,5218$

- $0,5218-0,5766$

- $0,5766-0,6314$

- $0,6314-0,6862$

$0,6862-0,7410$

- $0,7410-0,7958$

0,7958-0,8506

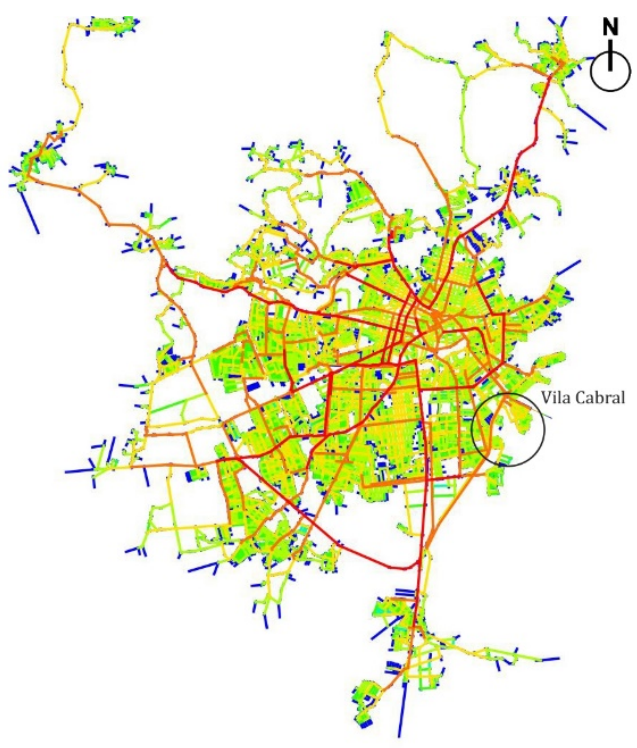

NACH_2020

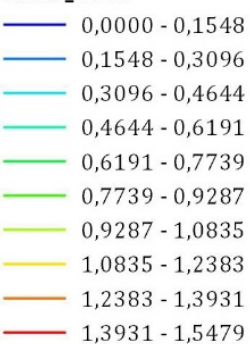

Figure 7. 2005 Angular

Segment Analysis $r=1200$ NAIN/NACH.

Source: the authors.

Figure 8. 2020 Angular Segment Analysis -Global NAIN/NACH.

Source: the authors. 
Figure 9. 2020 Angular Segment Analysis $r=1200$ NAIN/NACH..

Source: the authors.
Table 1. The general information of the Vila

Cabral urban fabric elements is arranged to compare the two scenarios.

Source: the authors.

Table 2. Objective results found analysing both scenarios.

Source: the authors.
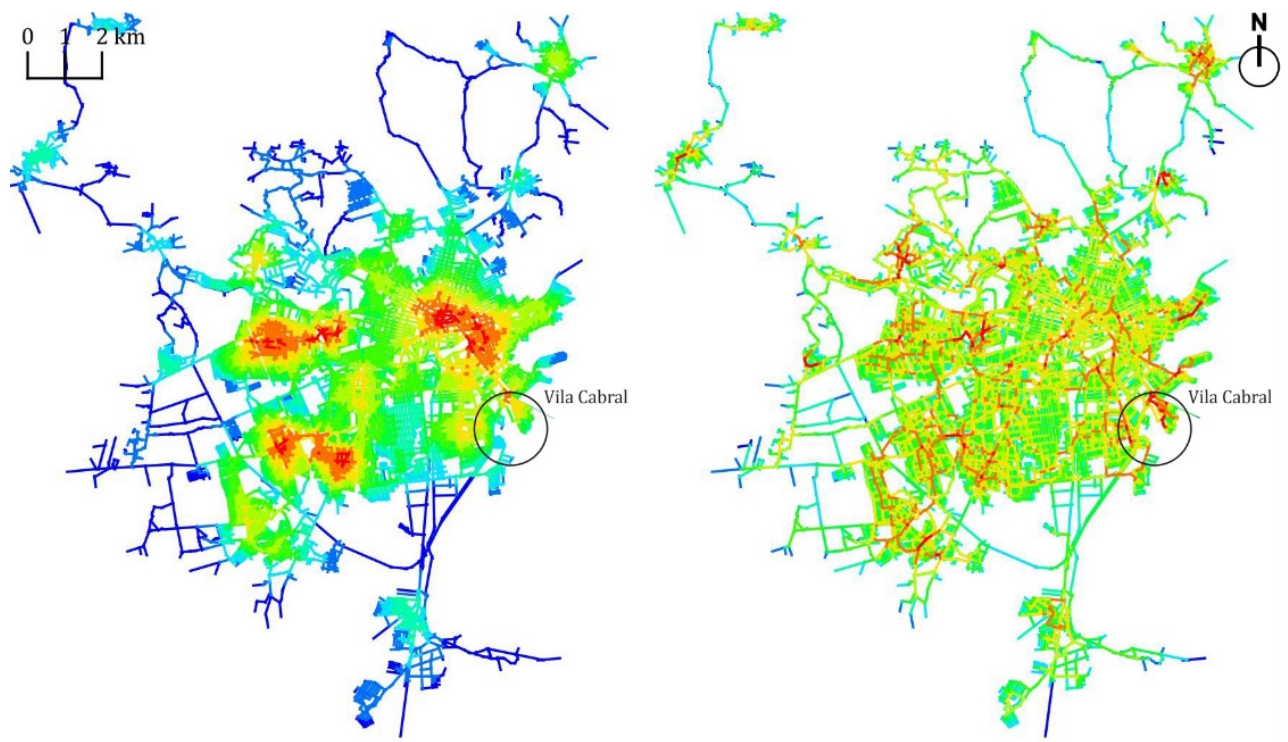

$$
\begin{aligned}
& \text { NAIN_R1200_2020 } \\
& \begin{array}{r}
0,0153-0,1918 \\
0,1918-0,3683 \\
0,3683-0,5449 \\
0,5449-0,7214 \\
\hline-0,7214-0,8979 \\
0,8979-1,0744 \\
1,0744-1,2509 \\
1,2509-1,4274 \\
-1,4274-1,6039 \\
-1,6039-1,7804
\end{array}
\end{aligned}
$$

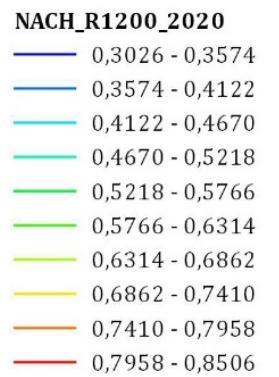

In the final step, after introducing the Grasshopper components developed to perform this evaluation and two tools of the CityMetrics system, the general information regarding the two scenarios (Table 1) was obtained as the objective number for the MXI, IUMTo, GSI, FSI, and OSR indicators. The results also include populational density in inhabitants per hectare (inhab./ha) for the two scenarios studied, which enabled a comparison of the results and an understanding of the changes that occurred in the neighborhood (Table 2).

\begin{tabular}{|c|c|c|}
\hline \multicolumn{3}{|c|}{ General Information } \\
Vila Cabral & $\mathbf{2 0 0 5}$ & $\mathbf{2 0 2 0}$ \\
\hline Total Area (Ha) & 105,15 & 122,63 \\
\hline Blocks Area (Ha) & 29,73 & 47,71 \\
\hline Total of Blocks & 57 & 72 \\
\hline Total of Plots & 1326 & 1546 \\
\hline Total of Buildings & 1263 & 1702 \\
\hline
\end{tabular}

Table 1 presents the general data related to both scenarios. In 2005, the sample had 105,15 hectares, with 29,73 occupied by 57 blocks, consisting of 1326 plots and 1263 buildings. In 2020 , the sample had a total area of 122,63 hectares, of which a total of 72 blocks occupied

\begin{tabular}{|c|c|c|c|c|c|c|c|c|c|}
\hline \multicolumn{5}{|c|}{2005 Scenario } & \multicolumn{5}{|c|}{2020 Scenario } \\
\hline \multicolumn{2}{|c|}{ Urban Diversity } & \multicolumn{3}{|c|}{ Built Density } & \multicolumn{2}{|c|}{ Urban Diversity } & \multicolumn{3}{|c|}{ Built Density } \\
\hline IUMTo & $\mathrm{MX}$ & GSI & FSI & OSR & IUMTo & $\mathrm{MXI}$ & GSI & FSI & OSR \\
\hline 0,8 & 0,7 & 0,17 & 0,22 & 3,77 & 0,72 & 0,64 & 0,21 & 0,43 & 1,83 \\
\hline \multicolumn{5}{|c|}{ Populational Density } & \multicolumn{5}{|c|}{ Populational Density } \\
\hline Gross & Net & \multicolumn{3}{|c|}{ Total inhabitants in the area } & Gross & Net & \multicolumn{3}{|c|}{ Total inhabitants in the area } \\
\hline 44 & 78 & \multicolumn{3}{|c|}{4668} & 91 & 138 & \multicolumn{3}{|c|}{11139} \\
\hline
\end{tabular}
47,71 hectares. Altogether there are 1546 plots and a total of 1702 buildings. 
The objective results found after the evaluation (Table 2) exposed that the study area is predominantly residential in both scenarios. Considering the street level, the IUMTo was equal to 0,8 in 2005 and 0,72 in 2020 . These values represent that $80 \%$ of the buildings were residential in 2005, decreasing to $72 \%$ in 2020. The Mixed-use Index (MXI) results were 0,7 in 2005 , and 0,64 in 2020 . These results show that the region had $70 \%$ of the total built area of residential buildings in 2005, decreasing to $64 \%$ in 2020 .

Regarding populational density, the study area contained 4668 inhabitants in 2005, with a gross density of 44 inhabitants /ha and a net density of 78 inhabitants/ha. In 2020, a total population of 11139 people was estimated, a significant increase, represented by a gross density equal to 91 inhabitants/ha and a net density of 138 inhabitants/ha.

Comparing the results of built density obtained in both scenarios (Figure 10), we can assume that the sample presents a slight variation in land occupation (GSI). The land occupation indicator (GSI) increased from 0,17 to 0,21. Regarding land use (FSI), the index almost doubled, going from 0,22 in 2005 to 0,43 in 2020. Table 2 also shows a drop in the Open Space Ratio (OSR) index, from 3,77 to 1,83 , which we already expected: the more buildings in the sample, the greater the pressure on open spaces. However, it is possible to assume that the FSI increase happens because of the Heron Marinho Business \& Living. This building contains a 20 floors business tower, two 30 floors residential towers, a tower with 130 flats spread over 22 floors, in addition to a hotel with 150 apartments.

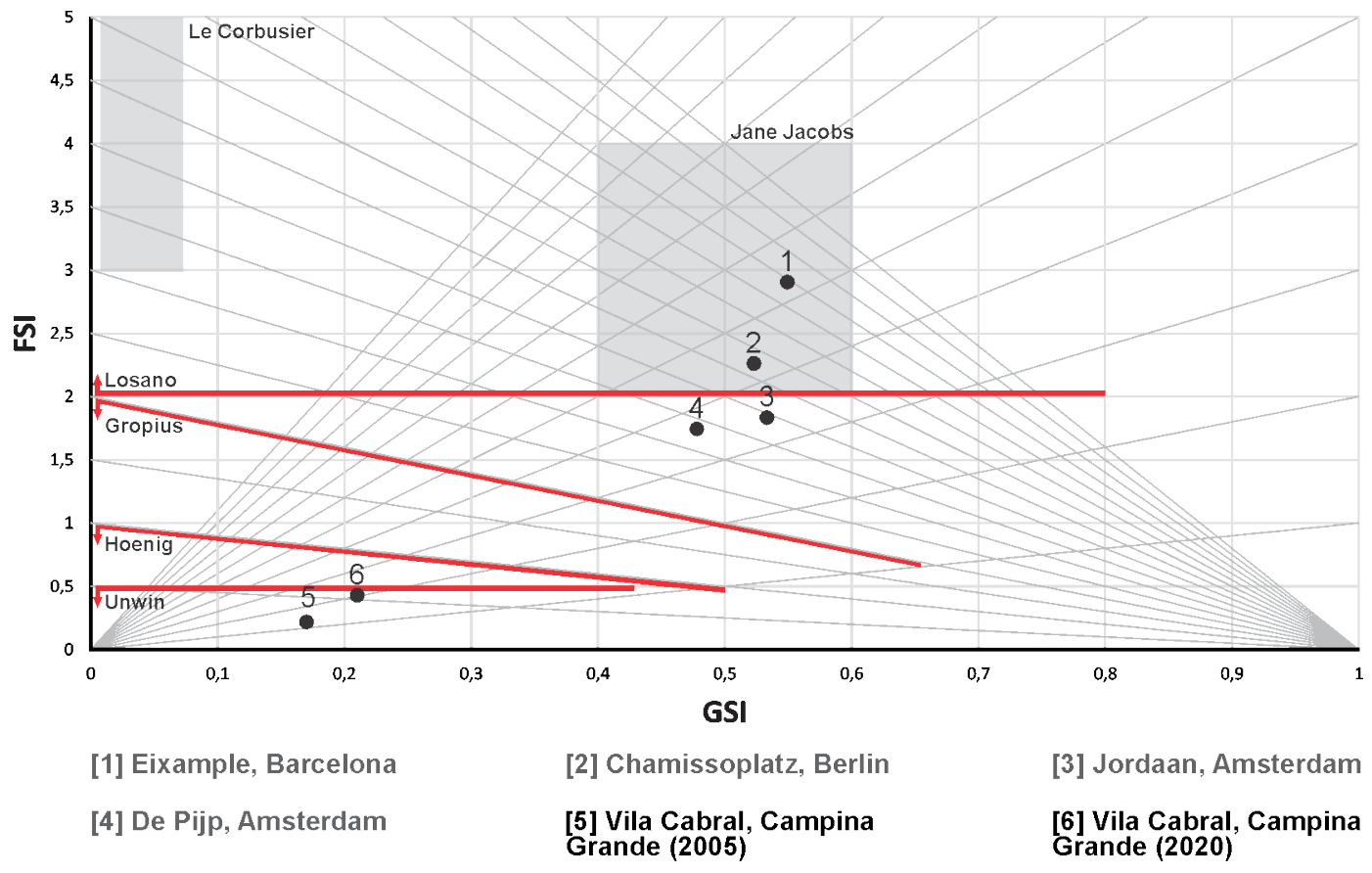

\section{DISCUSSIONS}

First, it is essential to highlight that we verified the influence of the two buildings in the Vila Cabral urban growth. The construction of UNIFACISA and Heron Marinho Business \& Living enhanced the changes in the neighborhood. We can state that the association between different methodological procedures and computational design tools (CDT) demonstrated efficiency in covering the evaluated points. The results exposed parameters of the neighborhood in many spheres, such as social, economic, densification, diversity, and spatial integration. Thus, the analysis proved interesting to diagnose morphological transformations through metric relationships and can be applied to create, design, and evaluate new urban design proposals.
Figure 10. Graph showing the two scenarios studied and four other cities evaluated by Berghauser Pont and Haupt (2010) in the SpaceMate diagram. The Graph also contains the regions that represent the understanding of urban space by some other authors.

Source: the authors, adapted from Berghauser Pont and Haupt (2010, p. 198).. 
As they deal with objective results, these procedures can support design decision-making in the context of Evidence-Based Design or Performance-Based Design.

The spatial configuration analysis through ASA - NAIN on a global scale pointed to a core with high integration values in the city's central area for both scenarios, with a more consolidated urban occupation in the year 2020. The analysis also evidenced the urban dispersion's enhancement by increasing less integrated spaces on a global scale (Rn) and a local scale (R1200). This dispersion is a consequence of the action of several urbanizing agents. ASA NACH on a global scale highlighted the main structural routes of Campina Grande, which play the role of bridge between the integrating core and the peripheral settlements of the city. This result expresses one reason that fosters the action of urbanization agents in Vila Cabral: the neighborhood is located close to these main roads.

Regarding the ASA, considering the analysis on a global scale (Rn), the increase in the average values of integration shows greater accessibility in the neighborhood, representing a greater integration of the region with the rest of the city and confirming the expansion movement. The analysis on a local scale (R1200) demonstrates a considerable increase for (a) the higher integration values near the Heron Marinho; (b) the average integration values in the roads closest to UNIFACISA. These results demonstrate that the neighborhood also became more accessible on the pedestrian scale. Finally, ASA - NACH highlights an increase in streets with the most significant potential for movement from the increase in main routes based on the pedestrian scale.

The parametric analysis addressing objective metrics allowed us to verify an increase in the GSI (Ground Space Index), followed by a slight increase in the FSI (Floor Space Index). This increase in GSI means that the neighborhood continues to sprawl and occupy more and more ground. Simultaneously, the timid change in the FSI refers to low-density development (built and populational). The differences in the indicators perceived between this study's scenarios reflect the expansion of the urban fabric's edges occurring at Vila Cabral. Given these numbers, we can make the following generalization: the values tend to increase until the entire land occupation scenario is reached within than urban legislation allows (GSI $=0,50$ approximately); When the sample reaches the maximum GSI, considering a sustainable urban design context, the desired is that the value for the FSI is something around 4, representing an average pavement equal to just over 7 in the sample; This combination could allow the neighborhood to reach a more compactness level, providing better quality to the urban space (more efficient public transport; optimized logistics, water supply, and power distribution networks; reducing the total cost of urban management).

The central point of this study discussion is that the objective indicators evaluated enhanced, but this did not improve the region's qualitative aspects identified in this research's theoretical foundation. The Vila Cabral neighborhood's infrastructure was still quite deficient in 2020 . Despite the evolution of indicators, there is still a lot to be desired in spatial quality. These results reinforce the importance of discussing how to incorporate metrics into the urban design process. The first aspect we highlight is allowing designers to accurately assess the physical space conditions in a given sample, demonstrating which parameters are insufficient. It is also possible to associate the metrics with CDT to explore rules and scenarios. This way, designers can quickly adapt and test parameters to local contexts and regulations through predictive modeling. The predictive urban modeling can support discussions to change local legislation and encourage/discourage specific occupation patterns suitable for a certain level of performance established after the evaluation.

The environmental impact is also another relevant issue. Campina Grande is situated in the semi-arid Brazilian northeast, a warm region that suffers from a rain deficit. In the following 
years, the decrease of green areas affects the soil's water absorption and the neighborhood's thermal comfort conditions. Therefore, to improve the Vila Cabral neighborhood, combining spatial interventions with social strategies is more effective than transforming its physical structure. In this sense, it is essential to highlight the importance of discouraging urban dispersion and urbanizing agents in the region through appropriate legal instruments.

We identified as a limitation of this investigation that using the neighborhood's administrative boundary as the urban fabric sample is not the best option to determine the analysis area. Spatial relationships transcend the municipality's administrative perimeter, evident through the neighborhood's systemic decomposition, which exposed two distinct areas in Vila Cabral. One possibility for improvement is to adopt a methodological proceeding that would help determine the sample boundary through spatial relationships. It is also essential to introduce qualitative approaches since understanding aspects of urban quality can only be achieved through analyses at various scales.

This study is passive of improvements, allowing more robust analysis within the Social Logic of Space scope. It is also possible to expand this research scope to other study samples by developing new parametric tools to evaluate new parameters related to different urban design paradigms. Thus, we intend to keep improving data collection procedures and evaluation for future studies and analyses, having as priorities (i) inserting aspects/indicators of environmental comfort on the urban scale; (ii) expanding this research scope to more neighborhoods. During the pandemic, with the high contagion by COVID-19, its mutations, and other possible airborne diseases, the refinement of analytical procedures and the addition of simulations with the ENVI-met software can emphasize open spaces and ventilation for blocks and urban buildings. Evaluating this aspect is a challenge for Brazil's warm and dry regions, as is Campina Grande and several other cities in the country's northeast. In such a context, CDT allows designers to more efficiently explore the volumetric diversity associated with key concepts, gaining awareness of possibilities, performance, and limits.

\section{Acknowledgments}

The authors want to thank the reviewers from the Sociedad Iberoamericana de Gráfica Digital (SIGraDi) and the journal Gestão \& Tecnologia de Projetos. The precise comments and contributions helped to improve the research and build a better structure for the paper. We are grateful for all the support and infrastructure available for this article's development. In particular, the Architecture and Urbanism Research Laboratory (DOMVS CNPq) and Performance and Innovation Applied to Design (DIAProj) group. We dedicate this work to our friend and supervisor, Geovany Jessé Alexandre da Silva (In memoriam). "Gigio" coordinated our researches with fundamental contributions and reflections, always wondering how to propose cities with more quality for people. He passed away from COVID-19 complications during the construction of this work, and we are very grateful that we learned from him. We carried out this work with scholarship funding from the Brazilian Coordination for the Improvement of Higher Education Personnel (CAPES) - Financing Code 001, Processes code 88887.541582/2020-00, and 88887.607971/2021-00.

\section{References}

ARAÚJO, C. M. "Áreas de risco" e problemáticas socioambientais: uma reflexão sobre a produção e apropriação do espaço urbano em Campina Grande PB. 2019. 314 p. Tese (Doutorado em Geografia) Universidade Federal da Paraíba, João Pessoa, 2019. 
Assessing Brazilian peripheral sprawl: an association of computer-aided tools to evaluate spatial changes at Vila Cabral neighborhood, Campina Grande

BEREITSCHAFT, B.; DEBBAGE, K. Urban form, air pollution, and $\mathrm{CO}^{2}$ emissions in large US metropolitan areas. The Professional Geographer, v. 65, n. 4, pp. 612-635, 2013. DOI:

https://doi.org/10.1080/00330124.2013.799991

BERGHAUSER PONT, M.; HAUPT, P. Spacematrix: Space, Density and Urban Form. Rotterdam: NAI Publishers, 2010.

BRUECKNER, J. K. Urban sprawl: diagnosis and remedies. International Regional Science Review, v. 23, n. 2, pp. 160-171, 2000. DOI: https://doi.org/10.1177/016001700761012710

CHAKRABARTI, V. A country of cities: a manifesto for an urban america. New York: Metropolis Books, 2014.

COELHO, C. D. Os elementos urbanos. Lisbon: Argumentum, 2013.

CORREA, R. L. O Espaço Urbano. São Paulo: Ática, 2004.

COSTA, L. B. Estruturação da cidade de Campina Grande: as estratégias e intencionalidades do mercado imobiliário. 2013. 194 p. (Masters dissertation) - Centro de Ciências Exatas e da Natureza, Universidade Federal da Paraíba, João Pessoa, 2013.

DANTZIG, G.; SAATY, T. Compact City: a plan for a liveable urban environment. San Francisco: Freeman, 1973.

DE ROO, G. Environmental Planning in the Netherlands: Too Good to be True. From Command-and-control Planning to Shared Governance. Farnham: Ashgate, 2003

DUANY, A.; PLATER-ZYBERK, E. The Second Coming of the American Small Town. Wilson Quarterly, v. 16, n. 1, pp. 3-51, 1992.

EWING, R.; SCHMID, T.; KILLINGSWORTH, R.; ZLOT, A.; RAUDENBUSH, S. Relationship between urban sprawl and physical activity, obesity, and morbidity. American Journal of Health Promotion, v. 18, n. 1, pp. 47-57, 2003. DOI: https://doi.org/10.4278/0890-1171-18.1.47

FARR, D. Sustainable Urbanism: urban design with nature. New Jersey: John Wiley \& Sons, 2007.

FREY, H. Designing the city: Towards a more sustainable urban form. London: Taylor \& Francis, 2003.

FRUMKIN, H. Urban Sprawl and Public Health. Public Health Reports, v. 117, n. 3, pp. 201-217, 2002. DOI: https://doi.org/10.1093/phr/117.3.201

FRUMKIN, H.; FRANK, L.; JACKSON, R. J. Urban sprawl and public health: Designing, Planning, and Building for Healthy Communities. Washington: Island Press, 2004.

GEHL, J. Cities for people. Washington: Island Press, 2013.

GLAESER, E. Triumph of the City: how our greatest invention makes us richer, smarter, greener, healthier, and happier. London: Penguin Books, 2012.

GUIMARÃES, L. de S. O modelo de urbanização brasileiro: notas gerais. GeoTextos, v. 12, n. 1, pp. 13-35, 2016. DOI: http://dx.doi.org/10.9771/1984-5537geo.v12i1.14084

HAMILTON, D. K.; WATKINS, D. H. Evidence-based design for multiple building types. New Jersey: John Wiley \& Sons, 2008.

HILLIER, B.; HANSON, J. The social logic of space. New York: Cambridge University Press, 1984.

HILLIER; B.; YANG, T.; TURNER, A. Normalising least angle choice in Depthmap - and how it opens up new perspectives on the global and local analysis of city space. Journal of Space Syntax, v. 3, n. 2, pp.155-193, 2012.

HOEK, J. W. Towards a Mixed-use Index (MXI) as a tool for urban planning and analysis. 2008. Available at: http://joostvandenhoek.com/mediapool/80/805179/data/PhD_proceedings_2009_ layout_v10_spreads_hoek.pdf. Accessed 14 Mar. 2021.

IBGE - Instituto Brasileiro de Geografia e Estatística - 2019: Avaiable at: https://cidades.ibge.gov.br /brasil/pb/campina -grande/panorama>. Acessed in 21 Mar. 2021. 
JABAREEN, Y. R. Sustainable urban forms: their typologies, models, and concepts. Journal of Planning Education and Research, v. 26, n. 1, pp. 38-52, 2006. DOI: https://doi.org/ 10.1177/0739456X05285119

JENKS, M.; BURGESS, M. J. R.; ACIOLY, C.; ALLEN, A.; BARTER, P. A.; BRAND, P. Compact cities: sustainable urban forms for developing countries. London: Taylor \& Francis, 2000.

JENKS, M.; DEMPSEY, N. Future forms and design for sustainable cities. London: Routledge, 2005.

KENNEDY, C.; CUDDIHY, J.; ENGEL-YAN, J. The changing metabolism of cities. Journal of Industrial Ecology, v. 11, n. 2, pp. 43-59, 2007. DOI: https://doi.org/10.1162/jie.2007.1107

KENWORTHY, J. R.; LAUBE, F. B. Automobile dependence in cities: an international comparison of urban transport and land use patterns with implications for sustainability. Environmental Impact Assessment review, v. 16, n. 4-6, pp. 279-308, 1996. DOI: https://doi.org/10.1016/S0195-9255(96)00023-6

KOLOVOU, I.; GIL, J.; KARIMI, K.; LAW, S.; VERSLUIS, L. "Road Centre Line simplification principles for Angular Segment Analysis." In: ELEVENTH INTERNATIONAL SPACE SYNTAX SYMPOSIUM, Portugal, Lisbon, 11., 2017. Proceedings [...], Lisbon: Instituto Superior Técnico, Departamento de Engenharia Civil, Arquitetura e Georrecursos, 2017.

LIMA, F. T. A.; MONTENEGRO, N.; PARAÍZO, R. C.; KÓS, J. R. Citymetrics: sistema (para)métrico para análise e otimização de configurações urbanas. Oculum Ensaios, v. 16, n. 2, pp. 409-427, 2019. DOI:

https://doi.org/10.24220/2318-0919v16n2a4163

LIMA, F. T. A.; COSTA, F. R.; ROSA, A. Lógica algorítmica-paramétrica e urbanismo: uma revisão teórica e de modelos computacionais para projetos urbanos. Gestão \& Tecnologia de Projetos, v. 15, n. 2, pp. 84-97, 2020. DOI: https://doi.org/10.11606/gtp.v15i2.162710

MAIA, D. S. A periferização e a fragmentação da cidade: loteamentos fechados, conjuntos habitacionais populares e loteamentos irregulares na cidade de Campina Grande-PB, Brasil. Scripta Nova, v. 14, n. 331, 2010.

MAIA, D. S.; CARDOSO, C. A. A.; ALONSO, S. F; SILVA, R. B. S. As desigualdades socioespaciais expressas no habitar. In: ELIAS, D.; SPOSITO, M. E. B.; SOARES, B. R. (Eds.). Agentes econômicos e reestruturação urbana regional Campina Grande e Londrina. São Paulo: Outras Expressões, 2013, pp. 117-138.

MOURELATOS, Z. P.; ZHOU, J. A design optimization method using evidence theory. Journal of Mechanical Design, v. 128, n. 4, pp. 901-908, 2006. DOI: https://doi.org/10.1115/1.2204970

NECHYBA, T. J.; WALSH, R. P. Urban sprawl. Journal of Economic Perspectives, v. 18, n. 4, pp. 177-200, 2004. DOI: 10.1257/0895330042632681

NETTO, V. M.; KRAFTA, R. A forma urbana como problema de desempenho oimpacto de propriedades espaciais sobre o comportamento urbano. Estudos Urbanos e Regionais, v. 11, n. 2, pp. 157-180, 2009. DOI: https://doi.org/10.22296/2317-1529.2009v11n2p157

VAN NES; A.; BERGHAUSER PONT, M.; MASHHOODI, B. "Combination of Space Syntax with Spacematrix and The Mixed Use Index: The Rotterdam South Test Case." In: EIGHTH INTERNATIONAL SPACE SYNTAX SYMPOSIUM, Chile, Santiago de Chile, 8., 2012. Proceedings [...], Santiago de Chile: Pontificia Universidad Católica de Chile, 2012.

YAMU, C.; NES, A.; GARAU, C. Bill Hillier's Legacy: Space Syntax: A Synopsis of Basic Concepts, Measures, and Empirical Application. Sustainability, v. 13, n. 6, 3394, 2021. DOI: https://doi.org/10.3390/su13063394. DOI: https://doi.org/10.3390/su13063394

MARICATO, E. Para entender a crise urbana. Cadernos do Núcleo de Análises Urbanas, v. 8, n. 1, pp. 11-22, 2015.

NETTO, V. M.; KRAFTA, R. A forma urbana como problema de desempenho: o impacto de propriedades espaciais sobre o comportamento urbano. Revista Brasileira de Estudos Urbanos e Regionais, v. 11, n. 2, pp. 157-180, 2009. DOI: https://doi.org/10.22296/2317-1529.2009v11n2p157 
Assessing Brazilian peripheral sprawl: an association of computer-aided tools to evaluate spatial changes at Vila Cabral neighborhood, Campina Grande

NEWMAN, P. G.; KENWORTHY, J. R. Cities and automobile dependence: an international sourcebook. Brookfield: Gower Publishing, 1989.

NEWMAN, P.; KENWORTHY, J. Sustainable urban form: the big picture. In: BURTON, E.; JENKS, M.; WILLIAMS, K. (Eds.). Achieving Sustainable Urban Form. London: Spon Press, 2000, pp. 109-120.

NEWMAN, P.; KENWORTHY, J. Urban design to reduce automobile dependence. Opolis, v. 2, n. 1, pp. 35-52, 2006.

PORTER, G.; DE ROO, G. The end has no merit... In: DE ROO, G.; PORTER, G. (Eds.). Fuzzy Planning - The Role of Actors in a Fuzzy Governance Environment. London: Ashgate, Aldershot \& Routledge, 2007, pp. 1-20.

ROGERS, R. Cities for a small planet. New York: Basic Books, 1998.

RUEDA, S. La ciudad compacta y diversa frente a la conurbación difusa. Ciudades para un futuro más sostenible, v. 19, n. 1, pp. 69-80, 1997.

SANTOS, M. A Urbanização brasileira. São Paulo: Hucitec, 1993.

SILVA, G. J. A. Formas, usos e cenários urbanos: métricas para projetar bairros. Oculum Ensaios, v.18, e214697, 2021. DOI: https://doi.org/10.24220/2318-0919v18e2021a4697

Frederico Costa frederico.costa@arquitetura.uffif.br

Jaqueline Brandão jaquelinebrandaao@gmail.com

Geovany Silva

galexarq.ufpb@gmail.com
SQUIRES, G. D. Urban sprawl: Causes, consequences, \& policy responses. Washington: Urban Insitute Press, 2002.

STEIN $\varnothing$, N.; VEIRUM, N. "A Parametric Approach to Urban Design. In Digital design: the quest for new paradigms". In: 23RD ECAADE CONFERENCE, Portugal, Lisbon, 23., 2005. Proceedings [...], Lisbon: University of Lisbon, 2005

TALEN, E. Sprawl retrofit: sustainable urban form in unsustainable places. Environment and Planning B, v. 38, n. 6, pp. 952-978, 2011. DOI: https://doi.org/10.1068/b37048

TURNER, A. Angular analysis. In: 3RD INTERNATIONAL SPACE SYNTAX SYMPOSIUM, United States, Georgia, 3. 2001. Proceedings [...], Georgia: Georgia Institute of Technology, 2001. 